\title{
Technical Change, Non-Tariff Barriers, and the Development of the Italian Locomotive Industry, 1850-1913
}

\author{
Carlo Ciccarelli and Alessandro Nuvolari
}

The locomotive industry was one of the relatively sophisticated "high tech" sectors in which Italy, a late industrializer, was successful before 1913. Using technical data on the performance of different vintages of locomotives, we construct a new industry-level index of technical change. We also study the impact of different policy instruments (import duties, non-tariff trade barriers, and other discretionary interventions) in shaping the development of the industry. Our reassessment reveals not only the sound technological performance of Italian locomotives and successful industry growth, but also the critical role played by non-tariff barriers for the development of the industry.

$\mathrm{T}$ he relationship between the adoption of new technologies in developing countries and comparative economic development continues to generate considerable research in economics and economic history. ${ }^{1}$ In his work, Alexander Gerschenkon noted that the "technology gap" with respect to the technological frontier provides developing countries with the opportunity to quickly absorb the "backlog of technological innovations" of advanced countries and catch up with them (1962, p. 8). This process of international technology diffusion is purported to be at the root of convergence with Britain by several European countries during the nineteenth century (Landes 1969). However, catching up is by no means automatic. Rather, it requires a significant mobilization of resources, skills, and capitals over a broad front, often coupled with a complex "mix" of policy interventions towards infant industries,

The Journal of Economic History, Vol. 75, No. 3 (September 2015). C) The Economic History Association. All rights reserved. doi: 10.1017/S0022050715001114

Carlo Ciccarelli is Assistant Professor, Department of Economics and Finance, University of Rome "Tor Vergata", Via Columbia 2, 00133 Rome (Italy). E-mail: carlo.ciccarelli@uniroma2. it. Alessandro Nuvolari is Associate Professor, Institute of Economics, Sant'Anna School of Advanced Studies, Piazza Martiri della Libertà 33, 56127 Pisa (Italy). E-mail:alessandro. nuvolari@sssup.it.

We would like to thank Alberto Dalmazzo, Giovanni Federico, Stefano Fenoaltea, Alfredo Gigliobianco, Piero Muscolino, Tommaso Proietti, Gianni Toniolo, and Michelangelo Vasta for helpful discussions and suggestions. This article has also benefited from the comments of two anonymous referees, and of the participants at the economic history seminars at the Bank of Italy, and at the University of Siena.

${ }^{1}$ See Fagerberg (1994) for a useful survey. 
ranging from trade and industrial policies to other forms of government actions. $^{2}$

In his assessment of the policy mix adopted by Italian governments in the second half of the nineteenth century, Gerschenkron was characteristically blunt, pointing to a generalized "ineptness of government industrialization policies." In particular, he argued that Italian industrialization would have benefited from a more "rationally conceived and executed tariff." The structure of the tariff, favoring iron and steel in a coal-less country, represented a major impediment to the development of the Italian mechanical engineering industry, which "was largely left to its own devices" (Gerschenkron 1962, pp. 80-83). Other historians have instead argued that the sluggish development of the industry lay in the overall "technical and organizational backwardness of the sector" and not in mistaken policies. ${ }^{3}$

This article sheds new light on these issues by reassessing the case of the steam locomotive industry, one of the few relatively "high tech" sectors in which Italy was successful before 1913. The development of this industry was shaped by a complex mix of policies comprising trade policies, "non-tariff trade barriers," and other discretionary interventions. The locomotive industry, thus, constitutes a useful vantage point to reconsider the general effectiveness of the different types of interventions adopted by the Italian governments in the period 1850 1913.

Our analysis relies on a new index of technical change based on technical indicators of the performance of different vintages of steam locomotives. The dataset includes some six thousand steam locomotives in operation in Italy from 1839 to 1913 . The index casts doubt on the prevailing view that the market share of Italian steam locomotive manufacturers was severely limited by their technical backwardness. On the contrary, the new quantitative evidence on technical change suggests that the technical capabilities of Italian producers were fully adequate when compared to those of foreign producers. Efficient production required then an annual production of about 50 locomotives per firm. Tariff-based protectionism, with positive net protection in force since the mid-1880s, was not sufficient to reach this goal. Rather, this production level was

\footnotetext{
${ }^{2}$ For a recent compact treatment see Allen (2011). For a classical analysis of the case of South Korea, see Amsden (1989).

${ }^{3}$ According to Toniolo (1977, p. 672), a more favorable tariff could have resulted in an increase of some 50 percent of the output of the mechanical engineering industry, which in turn would have amounted to an increase of some 7 percent in aggregate industrial production in 1908.
} 
achieved through specific procurement policies assuring regular orders to national producers. It was these non-tariff barriers that played a critical role for the development of the Italian locomotive industry.

\section{THE STEAM LOCOMOTIVE INDUSTRY IN ITALY: BACKGROUND}

At the point of political unification of Italy in 1861, the railway network was limited with about $3,900 \mathrm{~km}$ in 1864 , against $18,000 \mathrm{~km}$ in the United Kingdom, 16,000 km in Germany, and 12,000 km in France and the system had an eminently local character, as a result of the uncoordinated investments of the different pre-unitarian states in railway infrastructure. Political unification provided a major stimulus towards the expansion of the network, so that by 1910 the network comprised about 15,300 km. However, even after unification, various sections of the network were operated by several private franchise companies. A major reorganization took place in 1885 with "Railways Conventions" assigning the management of the network to three major private franchise companies under a renewable contract: the Rete Adriatica (RA) and the Rete Mediterranea (RM) covering the peninsula along a west-east divide, and, the Rete Sicula (RS), operating in Sicily. ${ }^{4}$ In 1905 the operation of the railway network was nationalized and taken over by the Ferrovie dello Stato (a big state-owned company with about 100,000 workers).

Debates on Italian industrialization initially focused on the relation between railway extension and market unification (Romeo 1959; Sereni 1966), and on the connection between the development of the railway network, the demand for industrial products, and the rate of economic growth (Gerschnekron 1962). To date, the most comprehensive economic appraisal of the relation between railroads and industrial growth in postUnification Italy is Stefano Fenoaltea $(1983,2011)$. Fenoaltea's appraisal points to the importance of the composition of investment. From 18611895, investment was devoted to construction of railway tracks (mostly using unskilled workers for earthworks and related activities) with a relatively reduced share (10 percent) devoted to the purchase of metalmaking or engineering products. From 1896-1913, the share of investment devoted to engineering products rose to about 30 percent of the total annual railway investment. Most importantly, maintenance (both

\footnotetext{
${ }^{4}$ For a more detailed outline of the historical evolution of the railway system in Italy, see the online Appendix, and reference therein.
} 
of railway lines and of rolling stock) grew throughout this period so that by 1913 it was such that, "on a value added basis, the maintenance of [rolling stock] was as important as their initial fabrication and, unlike the latter, it was immune from foreign competition" (Fenoaltea 1983, p. 49).

From an engineering standpoint, the steam locomotive is a sophisticated piece of equipment, comprising hundreds of parts, most of them requiring accurate manufacturing and processing. Philip Scranton (1997, p. 99) regards steam locomotives as a quintessential example of nineteenth century "specialty production": "no specialty product was then more complicated than a railway engine and few were as heavily taxed in use." Mass production was not feasible: steam locomotives were manufactured in small batches and they often had to incorporate particular specifications requested by individual customers. This meant that locomotive manufacturers had to marshal a significant breadth of engineering competences and skills. Even if the broad contours of locomotive design were established by the $1850 \mathrm{~s}$, throughout the second one-half of the nineteenth century, steam locomotives underwent a stream of technical improvements, which compelled a continuous revision and updating of many details of locomotives design and manufacturing. ${ }^{5}$

For these reasons, the steam locomotive provides an interesting perspective on the absorption of an "advanced" technology by latecomer countries. In comparative perspective, it is possible to distinguish two main "waves" in the international diffusion of the steam locomotive. During the first wave (1830-1860), the manufacturing of steam locomotives became established in England, Belgium, France, United States, and Germany. During the second wave (1880-1920), we witness the emergence, with varying success, of the manufacturing of steam locomotives in Italy, Russia, Spain, and Japan. ${ }^{6}$

${ }^{5}$ See Sinclair (1907). According to Greggio and Kalla-Bishop (1985, p. 99), "It was not until 1890 that fundamental design theory could be said to be settled, for what was decided then lasted until the end of steam." Analogously, Cardwell (1994, p. 348) regards the end of the nineteenth century as the moment in which the locomotive had reached "a point of nearperfection."

${ }^{6}$ The domestic production of steam locomotives in Spain remained limited until WWI. See Comín et al. (1998) and Cayón García and Muñoz Rubio (2005). On the more successful Japanese case, see Ericson (1998). In the Italian case, the production of steam locomotives has been investigated by Merger (1986, 1989), and, more recently, by Ciccarelli and Fenoaltea (2012). The works by Merger are mainly concerned with the production of national manufacturers in quantitative terms and do not consider in detail the technological performance of the different models of locomotives. Ciccarelli and Fenoaltea (2012) present annual estimates for the railguided vehicles industry both at the national and regional level. 


\section{THE STEAM LOCOMOTIVE INDUSTRY IN ITALY: NEW EVIDENCE, NEW CONJECTURES}

The evidence presented in this article is largely based on a new dataset described in the Appendix. It comprises two major components. The first one includes information on 5,700 locomotives, both domestic and foreign. For each locomotive we know the year and place of production, the producer's name, and a numerical identifier. The second component is based on the authoritative handbook by Giovanni Cornolò (1998) providing technical characteristics and performances of the locomotives for the period 1850-1913. By combining these two components we can chart in detail the technological characteristics of the different locomotives operating in each year.

\section{The Process of Import-Substitution}

The development of Italy's locomotive market is described in Figure 1 and Table 1 illustrating both the total number of locomotives and those produced domestically.

Until mid-1880s, domestic production was limited and the market was dominated by foreign manufacturers. The Italian import market was initially dominated by English producers, then by French producers, and finally by German manufacturers for whom, the Italian market was particularly significant. The Maschinenfabrik Esslingen, among the leading German producer of steam locomotives, exported during the period 1883-1887 about one-half of its production in Italy (Hertner 1984, p. 30). Furthermore, as noted by Albert Schram (1997, p. 61) German banks backed the Rete Mediterranea, and the Railways Conventions of 1885 marked the beginning of German investments in Italy. During the 1890s few locomotives were purchased, but after 1900, demand resumed with Italian producers substantially increasing their market share.

Using data on the number of locomotives, Michèle Merger (1986, 1989) argues that the limited production of Italian manufacturers during the period 1861-1885 is due to three concomitant factors: the limited depth of technological capabilities of national firms, a lack of specialization leading to increasing costs, and the penalties induced by the tariff on iron. After 1885, with the new Railways Conventions, a new wave of investments took place. In this phase Merger argues that the increased domestic production was a result of the public policies favoring national 


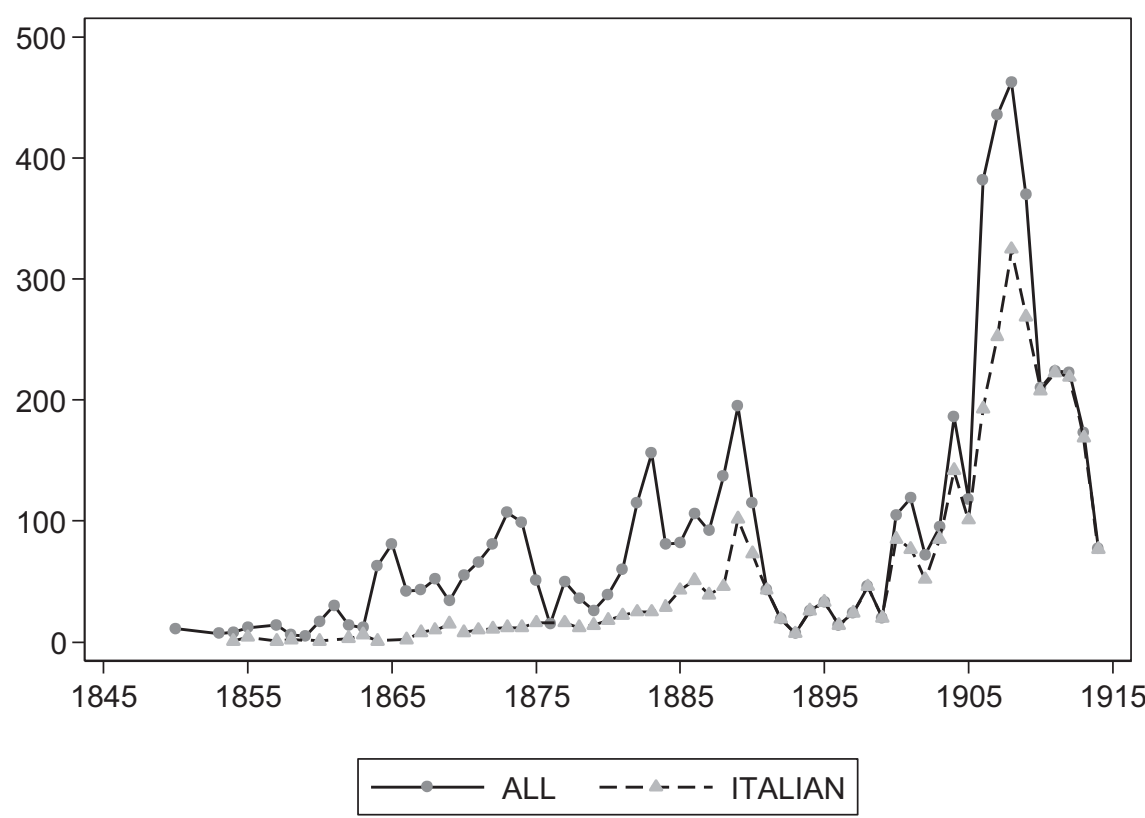

FIGURE 1

ESTIMATED ACQUISITIONS OF STEAM LOCOMOTIVES IN ITALY, 1850-1913 (UNITS)

Source: See Appendix.

manufacturers, in particular Pietrarsa, Ansaldo, and Breda. ${ }^{7}$ The ultimate consolidation of the national industry of steam locomotives, according to Merger, takes place after 1905 when the production of private national producers is elicited by a new wave of investment following the creation of Ferrovie dello Stato (FS), the new public operating company managing the entire main network (including both new construction and maintenance of the railway lines, and the maintenance of rolling stock). However, the increase in the number of domestically-produced locomotives tells us little about their technical quality.

\section{Patterns of Technical Change}

We assess the dynamics of technical change using the traditional weight-to-power $(w h p)$ ratio, a synthetic indicator that is widely used in

\footnotetext{
${ }^{7}$ These companies had been able to develop a certain base of engineering capabilities in locomotive building by virtue of different channels of knowledge transfer (recruitment of foreign personnel, travels abroad, and licensing of foreign patents), see Merger (1986) and Vasta (2002).
} 
TABLE 1

ESTIMATED ACQUISITIONS OF STEAM LOCOMOTIVES: TOTAL, DOMESTIC, AND FOREIGN PRODUCTION, 1850-1913

\begin{tabular}{lrrrrrrr}
\hline \hline & \multicolumn{3}{c}{ Units } & & \multicolumn{2}{c}{ Percentages } \\
\cline { 2 - 4 } \cline { 7 - 8 } Period & $\begin{array}{c}(1) \\
\text { Total }\end{array}$ & $\begin{array}{c}(2) \\
\text { Italian }\end{array}$ & $\begin{array}{c}(3) \\
\text { Foreign }\end{array}$ & & $\begin{array}{c}(4) \\
\text { Italian }\end{array}$ & $\begin{array}{c}(5) \\
\text { Foreign }\end{array}$ \\
\hline $1850-1860$ & 80 & 9 & 71 & & 11 & 89 \\
$1861-1870$ & 426 & 53 & 373 & & 12 & 88 \\
$1871-1880$ & 570 & 121 & 449 & & 21 & 79 \\
$1881-1890$ & 1,139 & 455 & 684 & & 40 & 60 \\
$1891-1900$ & 337 & 317 & 20 & & 94 & 6 \\
$1901-1914$ & 3,148 & 2,393 & 755 & & 76 & 24 \\
$1850-1914$ & 5,700 & 3,348 & 2,352 & & 59 & 41 \\
\hline
\end{tabular}

Source: See text.

the engineering literature and represents "a clear expression of technical progress" in steam locomotives (Diegoli 1961, p. 114). The whp ratio provides a measurement of the performance of the locomotive in a metric which is independent of its size, facilitating thus comparisons across different models and designs. ${ }^{8}$ For each locomotive we computed the $w h p$ ratio using the data from Cornolò (1998). The whp ratio represents, therefore, our proxy for the technical performance of the various "types" of locomotive, with lower values denoting better performance and thus improved technology. ${ }^{9}$ The different "types" of locomotives (Gruppi FS) were classified in 1905 by the engineers of the newborn Ferrovie dello Stato. Locomotives belonging to the same group are very similar in terms of technical characteristics. As Appendix A details, our sample includes more than 100 Gruppi FS. We construct an industry-level index (WHP)

\footnotetext{
${ }^{8}$ The $w h p$ ratio, as any other synthetic indicator of technological performance, has of course its own limitations. First, it is a ratio, so it is not directly telling on locomotive weight and power, each per se relevant. Second, the whp is not particularly informative on other technological characteristics such as, for instance, locomotive top-speed and fuel efficiency.

${ }^{9}$ An increase in locomotive power (due to the introduction of, say, a bigger boiler) leaving unaltered the whp ratio is not interpreted here as technological progress. The $w h p$ ratio is a performance indicator that seems particularly relevant in the Italian context also because "The Italian lines had numerous metal girders of moderate resistance, so the locomotives had to be of reduced weight, both per axle and per linear meter; as a consequence [Italian locomotives] were forced to have a particularly high power" (Diegoli, 1961, p. 108). From this point of view the evolution of Italy's steam locomotive sector during the nineteenth century can be understood as a struggle between the increasing weight of locomotives and rails' - of iron first of steel thencapability to bear it.
} 
of technical change as the weighted average of the technical performance of the different locomotive types entering in service in that year: ${ }^{10}$

$$
W H P_{t}=\sum_{g=1}^{G_{t}} s_{g t} w h p_{g}
$$

where $t$ represents time (year), and $s_{g t}=n_{g t} / N_{t}$ is the share of locomotive of type $g$ introduced in year $t$, (with $n_{g t}$ and $N_{t}$ indicating respectively the number of locomotives of type $g$, and the total number of locomotives, introduced in year $t) ; G_{t}$ denotes the number of the different types of locomotives introduced in year $t$, and $w h p_{g}$ is the weight-to-power ratio of locomotives of type $g .{ }^{11}$

This index comprises only the locomotives introduced in a given year. While the sources indicate systematically the year in which a locomotive entered in operation, the information about the year in which it was scrapped is not systematic. This prevents us from constructing the index for the composition of locomotives in operation in a given year. The index of technical change, therefore, should be regarded as an index representing the level of technological performance of the investment in locomotives in a specific year.

Figure 2 shows the evolution of the WHP index for Italian and foreign manufacturers. The area shaded in gray is delimited, year by year, by the maximum and minimum sample values of the WHP index. Interestingly enough, after 1870 , it is not uncommon to find Italian manufacturers among the best performers (locomotives with minimum value of the whp ratio in each year).

The WHP index is characterized by a decreasing trend, reflecting technical progress for both domestic and foreign locomotives. The first period (1850-1868) has wide fluctuations, which is an outcome of the limited sample size. The three decades from 1868 to 1898 shows substantial stability, with a rapid acceleration from 1898 to 1913 . This pattern is not surprising. Railways, in Italy as elsewhere, were first laid out across the plains. Conquering the mountains required more powerful locomotives and better railway infrastructures, including tracks, bridges, and embankments. The rapid acceleration observed in this last phase is concomitant with the introduction of two major

\footnotetext{
${ }^{10}$ Van Dijk and Szirmai (2006) have constructed a similar index of technical progress for the Indonesian pulp and paper industry.

${ }^{11}$ For example: if Group A includes ten locomotives with a whp index of 90, and Group B includes 40 locomotives with a $w h p$ of 70 , then $W H P=0.2 * 90+0.8 * 70=74$.
} 


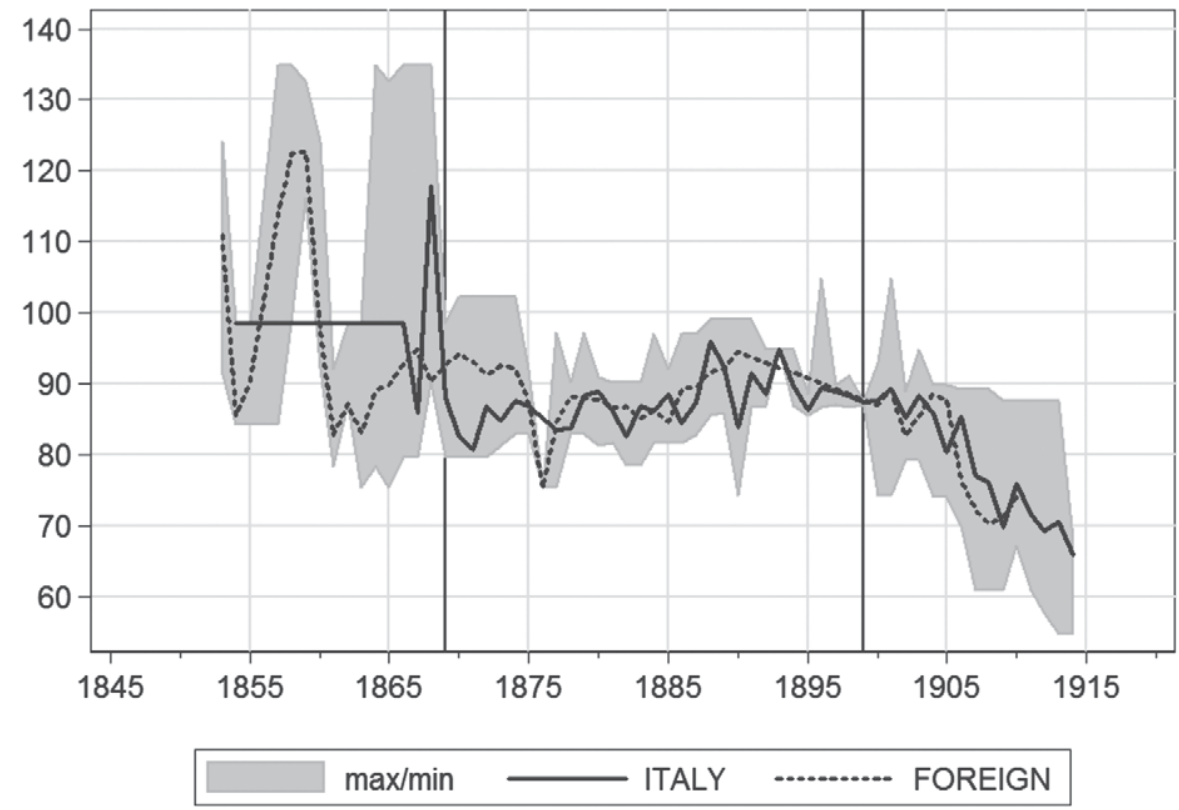

FIGURE 2

THE WEIGHT-TO-POWER INDEX (WHP), 1850-1913

Source: See text.

technical innovations: compounding and super-heating (Tey 1910, pp. 28-36; Diegoli 1961, pp. 108-9), both of which reduced the weight-topower ratio. Compounding and super-heating were the key features of the "second-generation" of steam locomotives. ${ }^{12}$ Compound locomotives were adopted in 1894 by the Rete Mediterranea and only later by its competitor, Rete Adriatica. Table 2 complements Figure 3 by reporting the average $W H P$ by decade separately for foreign and domestic producers; figures on the main Italian producers of the time are also reported in columns 3-5.

The evidence presented so far is not consistent with the limited engineering capacity suggested by the prevailing literature (on this point see Fenoaltea 2011, p. 150). Rather it supports contemporary views arguing that, at least from the late 1870 s, Italian manufacturers were indeed capable of designing and producing steam locomotives of quality fully comparable to that of foreign competitors, or, more precisely, of the models of locomotives that English, French, and German manufacturers

\footnotetext{
${ }^{12}$ Both innovations can been seen as the response to the threat of the electric locomotives in their pioneering phase after 1900 .
} 
TABLE 2

THE WEIGHT-TO-POWER INDEX (WHP), 1850-1913 ${ }^{\mathrm{a}}$

\begin{tabular}{|c|c|c|c|c|c|}
\hline \multirow[b]{2}{*}{ Period } & \multirow[b]{2}{*}{$\begin{array}{l}(1) \\
\text { Foreign }\end{array}$} & \multirow[b]{2}{*}{$\begin{array}{l}(2) \\
\text { Italian }\end{array}$} & \multicolumn{3}{|c|}{ Main Italian Producers } \\
\hline & & & $\begin{array}{c}(3) \\
\text { Ansaldo }\end{array}$ & $\begin{array}{l}(4) \\
\text { Breda }\end{array}$ & $\begin{array}{c}(5) \\
\text { Pietrarsa }\end{array}$ \\
\hline $1850-1860$ & 106.25 & 98.56 & 98.56 & - & - \\
\hline $1861-1870$ & 89.64 & 96.07 & 98.56 & - & 92.61 \\
\hline $1871-1880$ & 88.02 & 85.69 & 87.97 & - & 85.72 \\
\hline $1881-1890$ & 88.63 & 87.43 & 85.58 & 92.35 & 88.00 \\
\hline 1891-1900 & 87.00 & 89.20 & 91.65 & 87.81 & - \\
\hline 1901-1914 & 79.14 & 77.87 & 78.07 & 73.63 & - \\
\hline
\end{tabular}

${ }^{\text {a }}$ The table reports the average value of WHP. The dash denotes missing data in our sample. Breda was only created in mid-1880s, Pietrarsa switched from new production to maintenance in the 1890s.

Source: See text.

were importing in Italy. For example, at a conference for the 1881 Milan Exposition, Professor Leonardo Loria stated:

The national locomotives are perfectly equal, both in terms of manufacturing and assembling of components, to the best foreign locomotives .... . Our locomotives are not anymore mere imitation of foreign locomotives, manufactured assembling a number of components imported from abroad, rather they are locomotives fully adapted to the special conditions of our railway network, almost completely manufactured by us, where our engineers introduce important innovations ... . And, as far as the cost of production is concerned, today we are not far away from foreign firms. (Loria 1881, pp. 76-77)

Additional corroboration of this point can be found in the detailed account of Cornolò who mentions other models of locomotives (such as the "Ariosto" or the "Frescot") designed during the 1870s and early 1880 s that were crowned with critical acclaim at international exhibitions, and in the engineering literature..$^{13}$

\section{Government Policy}

The domestic production of locomotives increased over the nineteenth century. In this section, we examine the impact of government policy on the growth of the industry. Interestingly, from 1870 to 1885 , several

\footnotetext{
${ }^{13}$ See in particular Cornolò (1998, p. 31).
} 
TABLE 3

IMPORT DUTIES IN THE EARLY 1870S: PIETRARSA (NAPLES)

\begin{tabular}{|c|c|c|c|c|c|}
\hline Product & $\begin{array}{c}(2) \\
\text { Weight } \\
(\mathrm{kg})\end{array}$ & $\begin{array}{l}\text { Unit Cost } \\
\text { (lire/kg) }\end{array}$ & $\begin{array}{c}(4) \\
\text { Total Cost } \\
\text { (lire) }\end{array}$ & $\begin{array}{c}(5) \\
\text { Unit Import } \\
\text { Duty } \\
\text { (lire/100kg) }\end{array}$ & $\begin{array}{c}(6) \\
\text { Total Impc } \\
\text { Duty }^{\mathrm{b}} \\
\text { (lire) }\end{array}$ \\
\hline \multicolumn{6}{|l|}{ Inputs: } \\
\hline $\begin{array}{l}\text { From Marseille: } \\
\quad \text { iron (plates) }\end{array}$ & 10,852 & 0.432 & $4,688.06$ & 4.62 & 501.36 \\
\hline iron (plates) & 8,959 & 0.283 & $2,533.61$ & 4.62 & 413.91 \\
\hline \multicolumn{6}{|l|}{ From England: } \\
\hline fabricated metal & 11,022 & 0.865 & $9,534.03$ & 11.55 & $1,273.04$ \\
\hline steel & 1,498 & 0.970 & $1,453.06$ & 13.86 & 207.62 \\
\hline copper & 1,580 & 2.270 & $3,586.60$ & 13.86 & 218.99 \\
\hline bronze & 819 & 2.170 & $1,777.23$ & 4.62 & 37.84 \\
\hline brass tube & 3,059 & 1.820 & $5,567.38$ & 23.10 & 706.63 \\
\hline pig-iron & 5,529 & 0.085 & 469.97 & exempt & 0.00 \\
\hline Total & $43,318^{c}$ & - & $29,609.94$ & - & $3,359.39$ \\
\hline
\end{tabular}

Final product:

Steam locomotive

$40,000^{c}$

4.00

$1,600.00$

${ }^{a}$ Col. $4=\operatorname{col} 3 *$ col. 2 . Once labor costs $(21,974.45$ lire $)$ and transport costs $(2,172.51$ lire $)$ are included, total costs amount to 53,752 lire.

${ }^{\mathrm{b}}$ Col. $6=$ col. $2 *$ col. $5 / 100$.

${ }^{c}$ The number of kilograms reported in the table $(43,318 \mathrm{~kg})$ refers to the weight of the inputs used to build a "standard" locomotive. Given the loss of weight of materials tied to the production process (called sfrido in the technical jargon) the final weight of the locomotive is lower than $43,318 \mathrm{~kg}$. For the sake of simplicity, the sources typically omit to consider the sfrido.

Source: Comitato dell'inchiesta industriale (1872, p. 58); Camera dei Deputati (1871, p. 112).

parliamentary select committees (PSCs) debated alternative forms of State intervention to sustain the national industry. Of particular relevance here are the early 1870s PSC "on industry," the late 1870s PSC "on railways," and the mid-1880s PSC "on the revision of the trade tariff."

The PSC "on industry" (Comitato dell'inchiesta industriale) investigated the capacity to compete with foreign producers and the ways in which custom duties increased domestic competitiveness. ${ }^{14}$ The engineering sector was one of the most debated with many observers and practitioners (including businessmen, managers, and engineers) interviewed. The main locomotive producers were Ansaldo (near Genoa, established in

\footnotetext{
${ }^{14}$ The board was promoted by Luigi Luzzatti, an economist and politician of the time, appointed Prime Minister in 1910. Luzzatti and Vittorio Ellena exerted a major influence on the diffusion of protectionism in Italy through the tariff reforms of 1878 and 1887. Pareto himself used to refer to the 1887 protectionist reform as the "Ellena-Luzzatti" tariff (Pareto 1891).
} 
1854) and Pietrarsa (near Naples, established in 1842). They were asked about the effects of import duties on the domestic production of steam locomotives. Both Ansaldo and Pietrarsa argued that the tariff structure worked against the domestic production of locomotives. ${ }^{15}$ Tables 3 and 4 reproduce the evidence referring to the Pietrarsa (Naples) and Ansaldo (Genoa) workshops. ${ }^{16}$

Table 3 reports the cost structure of a typical locomotive of the Pietrarsa workshop. Column 2 shows that some 70 percent of a "standard" steam locomotive was made of iron, while the remaining 30 percent was of pig-iron, brass-tubes, copper, steel, and bronze. Column 4 reports the total physical cost of production (excluding labor and transport costs). The total cost of materials was 29,610 lire, and 32,970 lire once import duties are included (corresponding to a 10 percent increase). The last line shows that the import duty on a steam locomotive considered as a finished product amounted to 4 lire per $100 \mathrm{~kg}$. With a total weight of 40 tons, the import duty amounted to 1,600 lire. ${ }^{17}$ The tariff's structure, therefore, implied an additional cost of 3,360 lire for domestically-produced locomotives relative to 1,600 lire for imported locomotives, resulting in a negative protection for Italian locomotive producers.

Table 4 reports similar data provided by Ansaldo. For a standard " 1858 Government type" locomotive, the import duties on raw materials were 2,811 lire, well above the 1,570 lire paid as duty to import the same locomotive from abroad. Although the calculations by Ansaldo are extremely coarse, they show that in the early 1870s at least one-half of a locomotive was made up of highly-protected-iron, amounting to a negative protection.

The PSC "on industry" concluded that: "there is no balance between the ("high") tariff on iron and the one ("low") on machines"; therefore "it is necessary to reduce the tariff on iron," or "alternatively, it is necessary to raise the tariff on machines" (Comitato della inchiesta industriale 1874, p. 6). In fact, both the duties on iron and locomotives were raised over time. In the subsequent PSC "on railways" (Commissione d'inchiesta sull'esercizio delle ferrovie italiane), Pietro Peirano, a manager of

\footnotetext{
${ }^{15}$ As already noticed by Ciccarelli and Fenoaltea (2012), Felice Giordano-in his 1864 appraisal of the iron and metal working industry in Italy - argued convincingly that the engineering establishments of Naples and Genoa could potentially produce locomotives at prices that were similar to that of foreign ones. The argument made by Giordano refers to total cost of production, so that while iron was surely more expensive in coal-less Italy, labor was there relatively cheaper than in other countries (Giordano 1864, pp. 102, 359).

${ }^{16}$ The sources report an import duty on steam locomotives of 4 lire per $100 \mathrm{~kg}$ in one case (Pietrarsa), and 4.62 lire per $100 \mathrm{~kg}$ in the other (Ansaldo). From that evidence one can infer that in one case (Pietrarsa) the data refer to some year between 1866 and 1870, while in the other case (Ansaldo) to either 1871 or 1872.

${ }^{17}$ Giordano $(1864$, p. 349$)$ reports an input weight loss that may reach some 25 percent for certain materials. As a result, the negative protection illustrated in Tables 3-4 is surely underestimated.
} 
TABLE 4

IMPORT DUTIES IN THE EARLY 1870S: ANSALDO (GENOA)

\begin{tabular}{lrcc}
\hline \hline \multicolumn{1}{c}{$(1)$} & $\begin{array}{c}(2) \\
\text { Weight } \\
\text { Product }\end{array}$ & $\begin{array}{c}(3) \\
\text { Unit Import Duty } \\
\text { (lire/100kg) }\end{array}$ & $\begin{array}{c}(4) \\
\text { Total Import Duty } \\
(\text { lire })\end{array}$ \\
\hline Inputs: & & & \\
iron (bars) & 20,000 & 4.62 & 924.30 \\
copper (fused) & 1,500 & 4.62 & 69.30 \\
copper (bars) & 560 & 13.86 & 77.62 \\
copper (plates) & 1,475 & 9.24 & 136.29 \\
copper (layers) & 400 & 9.24 & 36.96 \\
tin (rods) & 200 & 9.24 & 18.48 \\
steel (bars) & 500 & 13.86 & 69.30 \\
steel for wheels & 3,225 & 23.10 & 744.97 \\
steel for springs & 990 & 34.45 & 344.03 \\
brass (tubes) & 1,670 & 23.10 & 385.77 \\
brass (for seals) & 60 & 9.24 & 5.55 \\
pig-iron & 3,450 & exempt & 0.00 \\
Total & 34,030 & - & $2,811.28$ \\
Final product: & & & $1,572.18$ \\
Steam locomotive & 34,030 & 4.62 & \\
\hline
\end{tabular}

${ }^{\mathrm{c}} \mathrm{Col}(4)=\operatorname{col}(2) * \operatorname{col}(3) / 100$

Source: Comitato dell'inchiesta industriale (1873, p. 43).

Ansaldo confirmed that the key factor forcing his company to give up the production of locomotives was the penalty induced by the tariff rather than the lack or backwardness of technological competency. ${ }^{18}$ Ansaldo and Pietrarsa's delegates were also consulted by the PSC on "the revision of international trade tariff" (Commissione d'inchiesta per la revisione della tariffa doganale) instituted in the mid-1880s and reaffirmed that the cost of protecting the metal-making sector (with high import duties on iron and other production inputs) represented a still too heavy burden for the engineering sector. ${ }^{19}$

18 Peirano confidently stated "We could outcompete foreign firms if raw materials were exempted from import duties." Even if self-interested, in our view the statement probably reflects a sincere assessment. In the same interview it is also discussed the special procurement policy practiced by Ferrovie Meridionali in favour of Pietrarsa. Clearly, if Peirano had not been intimately convinced of the critical role of the tariff, the best course of action would have been to advocate for the extension of a similar procurement policy rather than the revision of the tariff (Commissione d'inchiesta sull'esercizio delle ferrovie italiane 1879, pp. 371-72).

${ }^{19}$ Commissione d'inchiesta per la revisione della tariffa doganale (1886, pp. 423-33). 


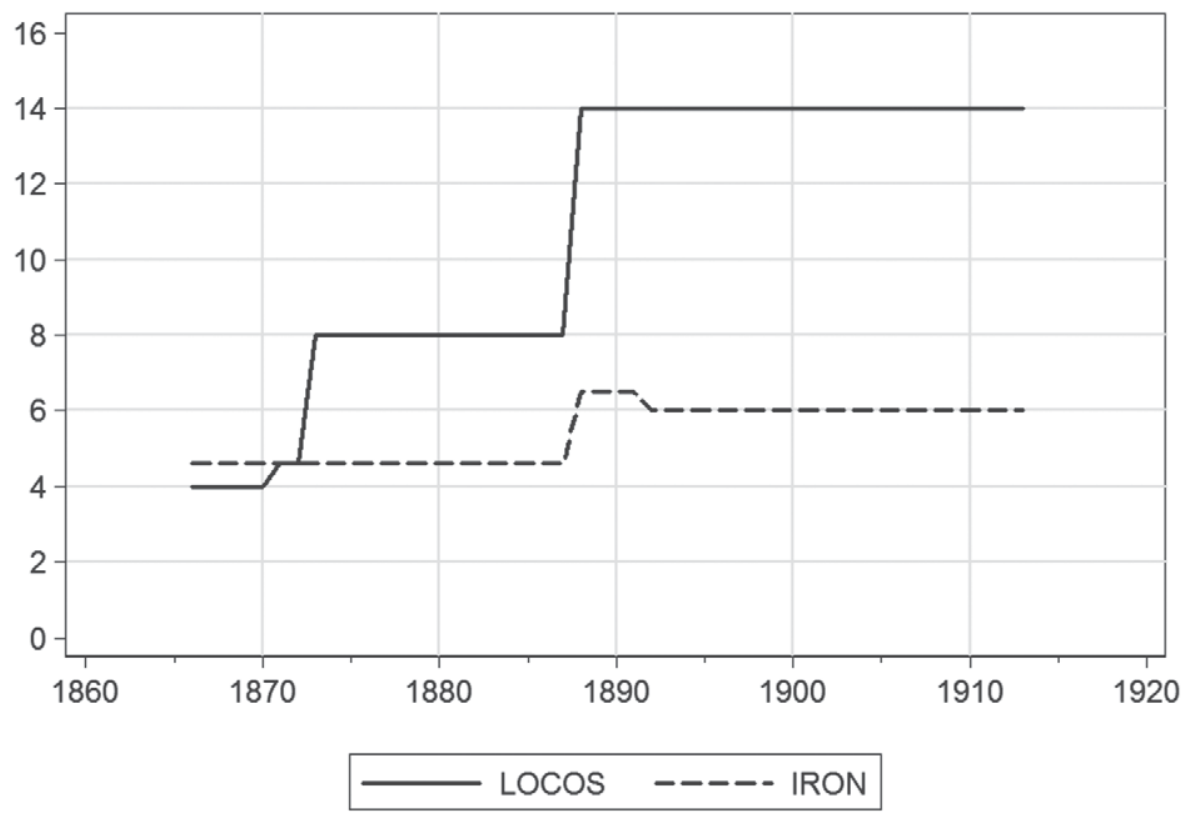

FIGURE 3

IMPORT DUTIES ON IRON AND STEAM LOCOMOTIVES: 1865-1913

(LIRE PER $100 \mathrm{KG})$

Source: See text.

\section{Net Protection on Steam Locomotives}

Figure 3 shows that subsequent tariff reforms-above all that of 1887-gradually ensured a positive protection to the Italian producers of steam locomotives. The vertical distance between the continuous and dashed line provides a measure of the net-protection on steam locomotives. Obviously the measure is rough for several reasons. Iron was not the only input in the production of a steam locomotive, though most relevant in terms of weight. Second, Italian import duties were mainly tied to weight (not to value), and thus less effective the higher the price of imported goods. Finally, but importantly, the inputs' weight losses occurring during the production process are not considered. Including them would shift the dashed line upward perhaps by as much as $20-30$ percent. ${ }^{20}$ Despite these limitations, Figure 3 tentatively suggests that the net protection on steam locomotives became positive over time: a

\footnotetext{
${ }^{20}$ This percentage is suggested by the early calculations reported in Giordano $(1864$, p. 349), and confirmed by the more detailed tables reported in the later Camera dei Deputati (1888, pp. $52-54)$.
} 
consequence of the increase, in different proportions, both of the import duties on iron and locomotives. Import duties on steam locomotives were raised from 4 to 4.62 lire in $1871 ; 4.62$ to 8 lire in $1873 ; 8$ lire to 14 from 1888. Import duties on iron were raised from 4.62 lire to 6.50 in 1888 and then lowered to 6.00 lire from $1892 .^{21}$

To sum up, the evidence we have discussed so far suggests that the structure of the tariff rather than alleged technological backwardness represented the main bottleneck stifling the expansion of the industry up to mid-1880s (Figure 2). ${ }^{22}$ This became less stringent as the effective rate of protection on steam locomotive rose in the late $1880 \mathrm{s.} .^{23}$ The growth in production after 1885 is generally seen as the result of two policy changes. The first is the aforementioned 1887 reform of the tariff, raising the import duty on steam locomotives from 8 to 14 lire per $100 \mathrm{~kg} .{ }^{24} \mathrm{The}$ second is the 5 percent clause introduced by the Railways Conventions of 1885 , which required that locomotives procurement contracts should be assigned to national manufacturers if their prices were less than 5 percent higher than the best offer of foreign competitors. ${ }^{25}$ This is a point of contention in the literature: several historians argued that the 5 percent

\footnotetext{
${ }^{21}$ Annual data on import duties are from the Movimento commerciale del Regno d'Italia, the official historical source on Italy's commercial flows. Data for the year 1874 are, for instance, from Ministero delle finanze (1875, p. 54 (locomotives) and p. 61 (iron)). Data for year 1888 are, for instance, from Ministero delle Finanze (1889, p. 218 (iron) and p. 256 (locomotives)). Data on steam locomotives are separately identified starting with 1886 . In the preceding years, the duties on steam locomotives were reported within the more general category of "steam machines." Data on iron refer to "ferro di prima fabbricazione" for the years 1866-1874, to "ferro laminato o battuto o in verghe di più di 5 millimetri di diametro" for the years $1870-1884$, and to "ferro e acciaio laminato o battuto o in verghe, spranghe o barre sagomate - non aventi in sezione alcun diametro o lato di 7 millimetri o meno" for the years after 1885. Luckily enough, overlapping retrospective figures are regularly reported in the source, allowing the reconstruction of plausible time-homogeneous series of import duties. Import duties for the years before 1865 were ad valorem and thus, for the sake of simplicity, here ignored.

${ }^{22}$ Thus confirming the intuition in Ciccarelli and Fenoaltea (2012, pp. 55-56).

${ }^{23}$ Federico and Tena (1999) have produced a detailed set of estimates of "effective rates of protection" by using the technical coefficients of three input-output tables (one for the United Kingdom in 1907, one for Italy in 1911, and one for Italy in 1950). Their estimates suggest that the effective protection rate for the mechanical engineering was probably not very different from zero or marginally positive over the period 1889-1913. Their estimates are therefore broadly consistent with the views of informed contemporaries discussed here.

${ }^{24}$ The 1887 tariff reform raised import duties on both iron and machines (including locomotives). Still the main Italian producers of steam locomotives were for the first time able to export their products. A possible explanation is that starting with late 1880s exporting firms were exempted from the payment of duty on iron. According to Società Italiana Ernesto Breda (1908, p. 50), Breda exported in the 1892-1902 decade 137 steam locomotives mostly in Romania and Denmark (Società Italiana Ernesto Breda 1936, p. 66); Popescu (1987, p. 333). It may be worth noting that the Romanian market of the time was dominated by major producers such as Beyer \& Peacock, Henschel, Maffei, and Wiener Lokomotivfabriks.

${ }^{25}$ Ministero dei lavori pubblici (1901, pp. 203-204); see in particular footnote 1.
} 
clause was probably too weak to exert a major impact (Gerschenkron 1962, p. 371; Caizzi 1965, p. 381; and Papa 1973, pp. 50-51), but the most recent contributions such as Merger (1986, p. 84), Giovanni Federico and Renato Giannetti (1999, p. 1134), and Giannetti and Michelangelo Vasta (2012, p. 226) claim rather that the clause played an important role in the "take-off" of domestic production of steam locomotives after 1885.

\section{The Silent Procurement Policy, 1885-1899}

There are, however, two other features of the Railway Conventions of 1885 that have received only limited attention in the literature, but are possibly far more important than the 5 percent clause and the revision of the tariff in accounting for the expansion of the domestic production. The first is the special endowment of 15 million lire granted, with the reorganization of the railway system in 1885 , to the three major operating companies to purchase railway equipment and material and also to renew their locomotive fleet (Merger 1986, p. 81). The second is the active procurement policy that was put in place after 1885, which, although not established by law, amounted to favoritism of "national champions" well beyond the preference arising from the 5 percent clause.

The point is clearly stated in an official publication of the "public works" ministry explicitly acknowledging that a segment of the Italian market for locomotives was to be reserved for national manufacturers:

In the case of locomotives the protection afforded by the aforementioned article [i.e., the five per cent clause], was not sufficient to allow national firms to win procurement contracts and, even a higher protection would have not been enough. Hence, in order to encourage the Italian locomotive industry, which is still in its infancy and it is practiced by very few firms that are now constructing the plants necessary to win against foreign competition, several procurement contracts have been assigned to these firms by means of private deals, fixing prices in such a way to allow these firms to manufacture locomotives without making losses and not making a too heavy burden for the State. (Ministero dei lavori pubblici 1889, pp. 501-2)

The 5 percent clause introduced by the Railway Conventions of 1885 was to be applied to contracts assigned by means of formal competitive calls ("licitazione"), but the franchise companies could also procure locomotives directly from the manufacturers outside of the competitive system as illustrated in Table 5.

Two points merit attention. Columns 4 and 5 show clearly that the 5 percent clause was insufficient to tilt the price advantage in favor of 
TABLE 5

ACQUISITIONS OF NEW LOCOMOTIVES: EXPENDITURE AND AVERAGE PRICE BY TYPES OF PROCUREMENT, 1885-1899

\begin{tabular}{|c|c|c|c|c|}
\hline $\begin{array}{l}\text { (1) } \\
\text { Type of Procurement } \\
\text { Contract }\end{array}$ & $\begin{array}{c}\text { (2) } \\
\text { Number of } \\
\text { Locomotives }\end{array}$ & $\begin{array}{c}(3) \\
\text { Total } \\
\text { Expenditures } \\
\text { (lire) }\end{array}$ & $\begin{array}{c}\text { (4) } \\
\text { Average Price } \\
\text { per Locomotives }\end{array}$ & $\begin{array}{c}(5) \\
\text { National/ } \\
\text { Foreign } \\
\text { Price }^{\mathrm{b}}\end{array}$ \\
\hline \multicolumn{5}{|l|}{ Open calls ${ }^{c}$} \\
\hline to foreigners & 291 & $17,299,848$ & $59,449.65$ & - \\
\hline to Italians & 0 & 0 & - & - \\
\hline National calls & 311 & $24,892,467$ & $80,040.09$ & 1.346 \\
\hline \multicolumn{5}{|l|}{ Direct procurement: } \\
\hline to foreigners & 46 & $2,217,898$ & $48,215.17$ & - \\
\hline to Italians & 284 & $21,112,045$ & $74,338.19$ & 1.541 \\
\hline Total & 932 & $65,522,258$ & - & - \\
\hline to foreigner & 337 & $19,517,745$ & $57,916.16$ & - \\
\hline to Italians & $595^{\mathrm{e}}$ & $43,392,879$ & $77,074.39$ & 1.331 \\
\hline
\end{tabular}

${ }^{a}$ Col. 4 = col. 3/col. 2 .

${ }^{\mathrm{b}}$ The national to foreign price ratio was obtained (rounding errors apart) as follows: $(80,040.09 / 59,449.65)=1.346 ;(74,338.19 / 48,215.17)=1.541 ;(77,074.39 / 57,916.16)=1.331$.

"Open calls ("licitazioni internazionali") were opened to both foreign and Italian producers

dNational calls ("licitazioni nazionali") were reserved for Italian producers.

${ }^{\mathrm{e}}$ The figure (595) also includes 32 locomotives built by the Mediterranea (30) and Adriatica (2) in their own workshops, accounting for a total value of 2,611,631.62 lire.

Source: Ministero dei lavori pubblici (1901, pp. 202-9).

national manufacturers. Second, a significant stimulus to the national industry was implemented by means of special deals. ${ }^{26}$ In particular, from the Railway Conventions of 1885 to 1900 , the domestic production of steam locomotives was assigned either by national auctions (284 units out of 595) or by private negotiations (311 units out of 595). To be sure, the price of foreign locomotives was lower than national ones, particularly so in the case of locomotive awarded through direct procurement contracts (about 74 thousands lire against about 48 thousands lire). Most likely, this price differential reflected both the possible higher efficiency of foreign producers, but also the existence of implicit agreements guaranteeing high prices to Italian producers.

\footnotetext{
${ }^{26}$ Calzavarini (1966, p. 74) points to the key role played by "non-tariff trade barriers" in compensating the "the insufficient protection of the trade regime." Calzavarini's appraisal has been largely neglected by the subsequent literature. For a useful discussion of non-tariff barriers, see Baldwin (1970).
} 
The adoption of stronger protectionist measures to favor Italian producers appears to be a leitmotiv of the parliamentary discussions. ${ }^{27}$ Despite various calls to exclude foreign locomotives, the government rejected such outright protection. However, the government agreed that, while the various forms of tariff protection were not sufficient, the most critical issue was the irregularity of demand. Informed contemporaries identify in the small and irregular number of orders the main problem affecting the cost competitiveness of national manufacturers. In 1881 Giuseppe Colombo wrote:

The convenient manufacturing of steam locomotives requires a demand of at least 50 units per year, and a workshop with the most sophisticated and specialized machinery. Two such workshops would probably suffice to supply the needs of whole Italian railway network. Given the methods of locomotives production prevailing today also in the major foreign firms, where many components are directly purchased by iron producers or other specialized manufacturers and ... given the proved ability of Italian producers in both new productions and maintenances ... the success of such undertaking in Italy would be, no doubt, possible. (Colombo 1881, p. 67)

A similar point was also stressed, a quarter century later, in the 1908 celebratory volume for the 1,000th locomotive constructed by Breda:

The technical difficulties that Breda had to face daily were exacerbated by two key factors: the fierce competition from foreign producers, and the irregular and discontinuous nature of the orders. (Società Italiana Ernesto Breda 1908, p. 22)

These statements suggest that more than the shield of tariff-based protection (with positive net protection effectively achieved from the late 1880s) it was the irregularity of demand that stymied the Italian manufacturers of steam locomotives during the nineteenth century. ${ }^{28}$

In this context, the Railway Conventions of 1885 played a critical role in reassuring the two main national manufacturers (Ansaldo and Breda) that the new political environment was going to be quite favorable to domestic producers of locomotives. This resulted in an expansion of

${ }^{27}$ An account of the passionate parliamentary debates on the locomotive industry at the turn of the century, not reported here for reasons of space, can be found in Ciccarelli and Nuvolari (2015).

${ }^{28}$ The highly irregular nature of the demand was not only a feature of the Italian market. For a discussion of the "feast-or-famine" nature of locomotive demand in this period in different countries, see Ericson (1998, pp. 133-34). 
the productive facilities of both firms so that domestic production increased relatively swiftly from a few units to more than a hundred units. $^{29}$

\section{THE BIRTH OF THE FERROVIE DELLO STATO (1905) AND THE NEW RAILWAYS POLICY}

The late nineteenth-century parliamentary debates on railways had important consequences in terms of actual economic policies. The government presented a plan concerning the acquisition of new rolling stock for the years 1900-1904. It was established (article 9 of law no. 57 of 27 February 1900) that the quantity, quality, and expenditure for new purchases of locomotives had to be agreed between the State and the operating companies. Furthermore, during the same five year period, the Government provided the companies a non-repayable grant of 28 million lire, reinforcing thus its role as chief sponsor of the railway sector. Not surprisingly, it has been remarked that the railway plan of 1900 represented the greater State commitment towards railway since the unification (Papa 1973, p. 50). In 1905, the 20-year contract between the State and the operating companies (the Railways Conventions of 1885) was not renewed and the State assumed the direct management of the railway system through the creation of Ferrovie dello Stato (FS), a fully public company.

The rules of the game were changed considerably. The new legislation established that "the Government will assign the production of new rolling stock to national manufacturers ... safeguarding, other things being equal, a fair distribution among the various producers" and "whenever necessary ... the executive manager [of the newborn FS] can disregard open and national call and use private negotiations ...", but importantly, "in case of collusive behavior or any kind of fraud by national manufacturers to the detriment of the railway administration [that is the FS], or when it will not be possible for national producers to guarantee a fair price of rolling stock, according to the prevailing market conditions, then ... [the Government] ... will order new rolling stock to foreign producers." ${ }^{30}$ Two points deserve attention. The first is that the tool of direct procurement to assign orders to national producers was explicitly

\footnotetext{
${ }^{29}$ On the investment in production capacity (in particular in that related to the production of locomotives) in the pioneering years of Breda, see Licini (1994).

${ }^{30}$ The framework of the new policy regime was established by law no. 137, April 1905 on "the public management of the railway sector," and by law no. 429, July 1907, on "the State management of railways not licensed to private firms." The citation refers to article 11 of law no. 137, April 1905.
} 
TABLE 6

DOMESTIC AND FOREIGN PRICES OF 403 LOCOMOTIVES ORDERED

IN JANUARY 1906, BY NATIONALITY OF THE PRODUCER

\begin{tabular}{|c|c|c|c|}
\hline Producer & $\begin{array}{c}\text { (1) } \\
\text { FS-Group }\end{array}$ & $\begin{array}{c}\text { (2) } \\
\text { Units }\end{array}$ & $\begin{array}{c}(3) \\
\text { Price } \\
\text { (lire per kg) }\end{array}$ \\
\hline \multicolumn{4}{|l|}{ A. Italians (direct procurement) } \\
\hline E. Breda Milano & 640 & 20 & 1.78 \\
\hline E. Breda Milano & 320 & 52 & 1.73 \\
\hline E. Breda Milano & 835 & 10 & 1.73 \\
\hline OM Milano & 320 & 20 & 1.73 \\
\hline OM Milano & 851 & 26 & 1.77 \\
\hline OM Saronno & 600 & 38 & 1.79 \\
\hline Giovanni Ansaldo Genova & 600 & 20 & 1.79 \\
\hline Giovanni Ansaldo Genova & 630 & 25 & 1.80 \\
\hline Giovanni Ansaldo Genova & 640 & 9 & 1.78 \\
\hline Giovanni Ansaldo Genova & 870 & 40 & 1.85 \\
\hline Giovanni Ansaldo Genova & 910 & 30 & 1.78 \\
\hline E. Breda Milano & - & 6 & NA \\
\hline Giovanni Ansaldo Genova & - & 10 & NA \\
\hline Total units & - & 291 & - \\
\hline Average price: & & & 1.77 \\
\hline \multicolumn{4}{|l|}{ B. Foreign (international auctions) } \\
\hline Maffei - Monaco ${ }^{\mathrm{b}}$ & 851 & 16 & 1.43 \\
\hline Ungarische S.B. Budapest & 600 & 9 & 1.48 \\
\hline Sigl, Wiener Neustdat & 600 & 24 & 1.65 \\
\hline Hartmann - Chemnitz & 600 & 12 & 1.65 \\
\hline Società Alsaziana Grafenstadt & 600 & 9 & 1.68 \\
\hline M. Fabrik Esslingen & 600 & 9 & 1.68 \\
\hline Schwazkopff - Berlino & 600 & 9 & 1.70 \\
\hline Energie Marcinelle & 600 & 12 & 1.72 \\
\hline Henschel - Cassel & 630 & 12 & 1.72 \\
\hline Total units: & - & 112 & - \\
\hline Average price: & - & - & 1.63 \\
\hline Average price of best offers ${ }^{\mathrm{c}}$ : & - & - & 1.56 \\
\hline
\end{tabular}

${ }^{\mathrm{a}}$ The total does not include one locomotive ordered to Breda and one to Ansaldo to be exhibited during the Milan 1906 exposition (Camera dei Deputati 1906a, p. 11).

${ }^{\mathrm{b}} \mathrm{A}$ few locomotives were sold by Maffei at the price of 1.50 lire per $\mathrm{kg}$ (Camera dei Deputati 1906a, p. 12).

'Following Camera dei Deputati (1906c, p. 13), and article 34 of Law 4297 July 1907 on the "State management of the railway sector") the average price of best offers is equal to 1.56 lire per $\mathrm{kg}$ and computed as $(1.43+1.48+1.65+1.68) / 4$.

Source: See text. 
TABLE 7

PRICE OF 403 LOCOMOTIVES ORDERED IN JANUARY 1906, AND TO BE DELIVERED BETWEEN JULY 1906 AND JUNE 1907

\begin{tabular}{lcc}
\hline \hline & $\begin{array}{c}(1) \\
\text { Price (lire per kg) }\end{array}$ & $\begin{array}{c}(2) \\
\text { National/Foreign Price }\end{array}$ \\
\hline $\begin{array}{l}\text { Italian locomotives } \\
\text { (via direct procurement) }\end{array}$ & 1.77 & - \\
$\begin{array}{l}\text { Foreign locomotives } \\
\text { (via open calls) }\end{array}$ & 1.63 & 1.086 \\
\hline
\end{tabular}

Source: Camera dei Deputati (1906a, p. 5).

institutionalized. The second is that the State intended to use international auctions as a threat to limit "extortionary" pricing by national producers. ${ }^{31}$ While the protection of the national industry was thus confirmed and even reinforced, a more rigorous expenditure policy was put in place.

Tables 6 and 7 document the effects of the new FS regime on locomotive acquisitions and prices. Table 6 provides quantity and price data from an official 1906 report. ${ }^{32}$ A total of 291 locomotives were assigned to national producers by direct procurement contracts, and 112 to foreign producers through international auctions. Table 7 provides an assessment of the price gap between national and foreign manufacturers in 1906. It shows that by 1906 the price gap was only about 9 percent, significantly lower than in the $1885-1899$ period. ${ }^{33}$

${ }^{31}$ Direct procurement contracts were rarely used to import locomotives from abroad. The Minister of public works Carmine mentions for instance the case of "unusual" private negotiations with foreign producers concerning 25 locomotives (Camera dei Deputati 1906b, p. 6652).

${ }^{32}$ The report of March 1906 to the Parliament by the Minister of public works Pietro Carmine (the so called "Carmine-report," Camera dei Deputati 1906a).

${ }^{33}$ The price ratio between national and foreign locomotives reported in Table 7 can be used to perform a tentative estimation of the total factor productivity (TFP) gap in steam locomotives production between Italy and Germany around 1906. We use the formula $\frac{A}{A^{*}}=\frac{\left(W / W^{*}\right)^{\alpha}\left(R / R^{*}\right)^{\beta}\left(C / C^{*}\right)^{\gamma}}{P / P^{*}}$, where $A=$ TFP levels; $W=$ real wages; $R=$ rental cost of capital; $C=$ raw materials and $\alpha, \beta$, and $\gamma$ are the shares of labor, capital, and raw material in total costs. The suffix * indicates the foreign country. Assuming that the rental cost of capital was the same in the two countries, using the data in Table 3 to estimate cost shares, data on real wages from Allen (2001), and on the price of iron (which approximates the raw materials) from Cianci (1933, pp. 329-30), one gets that the level of TFP in Italy was about 85 percent of the German level. Taking into account the crude nature of the data, the assumptions made, and that the extent to which the prices reported in Table 7 were subjected to political manipulation remains uncertain, these estimates provide only a very rough indication of the TFP gap between the two countries. 
To summarize, with the creation of the FS in 1905, the State implemented a new policy mix capable to stimulate the national industry, by directly assigning to local producers new locomotive orders, and, at the same time, to safeguard the State budget by linking the price effectively paid to national producers to the best offers of foreign producers. ${ }^{34}$ Foreign purchases were used to investigate the price of locomotives and to absorb demand peaks, as the one occurred in 1907-1908 when about 900 locomotives entered the FS locomotive fleet.

\section{CONCLUDING REMARKS}

Notwithstanding the limited endowment of the country in terms of engineering competences, the Italian steam locomotive industry achieved a level of technological sophistication in line with that of foreign producers by the beginning of the twentieth century. The early development of the industry was slowed both by the vagaries of the demand which prevented the major national players from planning an ordered expansion of productive capacity and, secondly, by tariff protection on iron products, which resulted in a cost disadvantage. From 1885 onwards national manufacturers received considerable support through a discretionary procurement policy which in practical terms amounted to an effective "non-tariff barrier" and to a more regular demand for their products, tied to the spread of the railways network leading to greater economies of scale.

The design and construction of locomotives were probably among the most sophisticated segments of the nineteenth century mechanical engineering industry and it is instructive to compare the performance of the locomotive industry with other less sophisticated branches such as cotton textile machinery where the country was unable to develop any autonomous production (Besso 1910, pp. 142-43; A'Hearn 1998). Yet, there were also other complex engineering products in which Italy was also able to deliver a very good performance, such as the production of warships (Fenoaltea 2011, p. 150), some of which were even exported. This somewhat paradoxical outcome can be explained taking into account that some of the most sophisticated branches of the mechanical engineering could endure the negative effects of the tariff, by virtue of non-tariff trade barriers such as public procurement, subsidies, and other similar policies, whereas the less sophisticated branches had to bear its full burden.

\footnotetext{
${ }^{34}$ For a more detailed discussion on the procedures to determine the price of steam locomotives after 1905 see Ciccarelli and Nuvolari (2015).
} 


\section{Appendix A The Steam Locomotives Dataset}

The steam locomotives dataset is based on two major components. The first one is constructed with the same approach and sources used in Ciccarelli and Fenoaltea (2012) for their statistical reconstruction of Italy's rail-guided vehicles industry. ${ }^{35}$ The second component is entirely new and covers indicators of technical characteristics and performances of locomotives.

The main source for the first component of the dataset is constituted by the catalogues of the principal companies operating the railways system at different moments in time. Catalogues of this kind were published from the late 1880 s by three main operating companies (Rete Adriatica (RA), the Rete Mediterranea (RM), and the Rete Sicula (RS)). ${ }^{36}$ A similar catalogue was published in 1914 by the Ferrovie dello Stato (FS), providing an exhaustive list of locomotives in operating service at the date of 30 June 1914. ${ }^{37}$ The catalogues set out the technical characteristics of each type of locomotive in service together with a numerical identifier, the year of construction, and the name of the building company. Our dataset is constructed by merging the relevant quantitative information stored in these four publications.

The second component of the dataset concerns technical features. For each locomotive model (Gruppo FS) we have retrieved the information on locomotives' weight and power (measured in HP) from Cornolò (1998, pp. 584-99).

The WHP calculations presented in the previous Patterns of technical change section refer to 4,432 steam locomotives with separated tenders; the remaining 1,268 tanklocomotives (locomotives carrying water and coal on board instead of pulling them behind in a separated tender), with a WHP far higher and well above 100, are excluded. ${ }^{38}$ Locomotives in our sample are grouped according to a classification scheme adopted by the Ferrovie dello Stato (FS) in 1905.

Table A1 illustrates the distribution of locomotives in our sample by (104) locomotive groups. The table includes two panels. Panel A includes locomotive groups from 100 to 560; these are mostly of "first-generation" (i.e., using single expansion and saturated, or "wet" steam). Panel B refers to groups from 600 to 980, and includes mostly "second generation" locomotives (i.e., adopting super-heating and/or doubleexpansion). The table's columns are numbered as follows. Odd numbers refer to locomotive groups. Even numbers refer to the units of locomotives within a given group. Locomotive groups included in the same column are similar in terms of technical characteristics (speed, power, weight, wheels arrangement, etc.). The bottom part of Table A1, panels A and B report the average sample weight, the average sample power, and the power-to-weight-ratio evaluated at the sample average.

\footnotetext{
${ }^{35}$ A complete account (in Italian) on sources and methods can be found in Ciccarelli and Fenoaltea (2014).

${ }^{36}$ Società Italiana per le Strade Ferrate Meridionali. Esercizio della Rete Adriatica (1887 ca), Società Italiana per le Strade Ferrate del Mediterraneo (1888), and Società italiana per le Strade Ferrate della Sicilia (1902 ca).

${ }^{37}$ Ferrovie dello Stato (1914).

${ }^{38} \mathrm{We}$ do not consider in our sample tank-locomotives because they are typically of reduced size and weight, and often operating in narrow gauge lines (Ministero dei lavori pubblici 1901, pp. 200-1, where the tank-locomotives are classified as a category apart, with an average price well below that of standard locomotives).
} 
TABLE A1

STEAM LOCOMOTIVES OPERATING IN ITALY, 1850-1914, BY GROUP

A. FS Groups 100-500: First Generation Machines

Locomotives with Separated Tender

\begin{tabular}{|c|c|c|c|c|c|c|c|c|c|}
\hline $\begin{array}{c}\text { (1) } \\
\text { Group }\end{array}$ & $\begin{array}{l}\text { (2) } \\
\text { Units }\end{array}$ & $\begin{array}{c}\text { (3) } \\
\text { Group }\end{array}$ & $\begin{array}{l}\text { (4) } \\
\text { Units }\end{array}$ & $\begin{array}{c}\text { (5) } \\
\text { Group }\end{array}$ & $\begin{array}{c}\text { (6) } \\
\text { Units }\end{array}$ & $\begin{array}{c}\text { (7) } \\
\text { Group }\end{array}$ & $\begin{array}{c}(8) \\
\text { Units }\end{array}$ & $\begin{array}{l}\text { (9) } \\
\text { Group }\end{array}$ & $\begin{array}{l}\text { (10) } \\
\text { Units }\end{array}$ \\
\hline 100 & 12 & 200 & 56 & $310 \mathrm{C}$ & 69 & 400 & 13 & 500 & 18 \\
\hline 102 & 8 & 206 & 64 & 320 & 201 & 410 & 25 & 510 & 142 \\
\hline 103 & 5 & 215 & 394 & 380 & 50 & 420 & 293 & 530 & 72 \\
\hline 111 & 8 & $255 \mathrm{C}$ & 6 & 385 & 19 & 450 & 8 & 540 & 18 \\
\hline 112 & 8 & 260 & 24 & 388 & 3 & 451 & 72 & 545 & 46 \\
\hline 113 & 25 & 265 & 30 & 390 & 9 & 470 & 143 & 550 & 18 \\
\hline 116 & 5 & 268 & 10 & 391 & 28 & 499 & 6 & 552 & 36 \\
\hline 118 & 7 & 269 & 6 & 395 & 5 & & & 560 & 31 \\
\hline 120 & 156 & 270 & 130 & 396 & 5 & & & & \\
\hline 136 & 27 & 290 & 338 & 397 & 3 & & & & \\
\hline 140 & 70 & & & & & & & & \\
\hline 155 & 39 & & & & & & & & \\
\hline 164 & 25 & & & & & & & & \\
\hline 170 & 73 & & & & & & & & \\
\hline 180 & 4 & & & & & & & & \\
\hline 183 & 12 & & & & & & & & \\
\hline 185 & 41 & & & & & & & & \\
\hline 190 & 97 & & & & & & & & \\
\hline asw & 34,777 & & 41,273 & & 41,357 & & 60,304 & & 44,255 \\
\hline$a s h p^{c}$ & 378 & & 461 & & 457 & & 711 & & 529 \\
\hline whpas $^{\mathrm{c}}$ & 92 & & 90 & & 90 & & 85 & & 84 \\
\hline $\min y e a r^{\mathrm{d}}$ & 1853 & & 1861 & & 1857 & & 1853 & & 1878 \\
\hline $\max y e a r^{\mathrm{d}}$ & 1889 & & 1913 & & 1908 & & 1912 & & 1901 \\
\hline
\end{tabular}


TABLE A1 (CONTINUED)

\begin{tabular}{|c|c|c|c|c|c|c|c|}
\hline \multicolumn{8}{|c|}{ B. FS Groups 600-900: Second-Generation Machines } \\
\hline \multicolumn{4}{|c|}{ Locomotives with Separated Tender } & \multicolumn{4}{|c|}{ Tank-Locomotives $^{\mathrm{b}}$} \\
\hline (1) & (2) & (3) & (4) & (5) & (6) & (7) & (8) \\
\hline Group & Units & Group & Units & Group & Units & Group & Units \\
\hline $600 \mathrm{C}$ & 248 & 720 & 10 & 800 & 18 & 900 & 18 \\
\hline $625 \mathrm{~S}$ & 98 & $730 \mathrm{C}$ & 190 & $801 \mathrm{C}$ & 9 & 902 & 12 \\
\hline $630 \mathrm{C}$ & 100 & $740 \mathrm{~S}$ & 135 & 802 & 3 & 905 & 84 \\
\hline $640 \mathrm{~S}$ & 169 & $745 \mathrm{~S}$ & 4 & 803 & 6 & $910 \mathrm{C}$ & 54 \\
\hline 650 & 55 & $750 \mathrm{C}, \mathrm{S}$ & 40 & 805 & 46 & 950 & 6 \\
\hline $656 \mathrm{C}$ & 25 & & & 810 & 13 & $980 \mathrm{C}$ & 12 \\
\hline $660 \mathrm{C}$ & 51 & & & 813 & 12 & & \\
\hline $666 \mathrm{C}$ & 10 & & & 815 & 2 & & \\
\hline $670 \mathrm{C}$ & 43 & & & 816 & 38 & & \\
\hline $680 \mathrm{C}, \mathrm{S}$ & 151 & & & 817 & 4 & & \\
\hline $685 \mathrm{~S}$ & 66 & & & 820 & 1 & & \\
\hline \multirow[t]{17}{*}{$690 \mathrm{~S}$} & 24 & & & 821 & 4 & & \\
\hline & & & & 822 & 2 & & \\
\hline & & & & 825 & 12 & & \\
\hline & & & & 827 & 20 & & \\
\hline & & & & 829 & 6 & & \\
\hline & & & & 830 & 44 & & \\
\hline & & & & 835 & 286 & & \\
\hline & & & & 848 & 2 & & \\
\hline & & & & 849 & 2 & & \\
\hline & & & & 850 & 5 & & \\
\hline & & & & 851 & 207 & & \\
\hline & & & & 870 & 168 & & \\
\hline & & & & 875 & 55 & & \\
\hline & & & & $885 \mathrm{C}$ & 16 & & \\
\hline & & & & 895 & 89 & & \\
\hline & & & & 898 & 5 & & \\
\hline & & & & 899 & 7 & & \\
\hline$a s w^{c}$ & 60,179 & & 66,531 & & 43,044 & & 58,857 \\
\hline$a s h p^{\mathrm{c}}$ & 860 & & 932 & & 380 & & 576 \\
\hline$w h p s a^{\mathrm{c}}$ & 69 & & 71 & & 113 & & 102 \\
\hline $\min y e a r^{\mathrm{d}}$ & 1884 & & 1902 & & 1850 & & 1886 \\
\hline $\max y e a r^{\mathrm{d}}$ & 1914 & & 1914 & & 1914 & & 1913 \\
\hline
\end{tabular}

${ }^{a}$ The table includes 5,700 steam locomotives operating in the standard-gauge (1,435 meters) Italian railway network. The $\mathrm{C}$ and $\mathrm{S}$ letters attached to groups' number denote respectively double-expansion and super-heating. The remaining cases consist of more traditional locomotives using saturated steam and simple expansion.

${ }^{\mathrm{b}}$ Groups FS 800 to 899 and 900 to 980 only include tank-locomotives (for a total of 1,268 units) and are not included in the evaluation of the WHP index illustrated in the main text.

'asw: average sample weight; aswp: average sample horse power; whpsa: weight-to-power ratio evaluated at sample average.

d min year: first entry year in the sample; max year: last entry year in the sample.

Source: See text. 


\section{The Italian Locomotive Industry, 1850-1913}

\section{REFERENCES}

Allen, Robert C. "The Great Divergence in European Wages and Prices from the Middle Ages to the First World War." Explorations in Economic History 38, no. 4 (2001): 411-47.

- Global Economic History. Oxford: Oxford University Press, 2011.

Amsden, Alice H. Asia's Next Giant. South Korea and Late Industrialization. Oxford: Oxford University Press, 1989.

A'Hearn, Brian. "Institutions, Externalities and Economic Growth in Southern Italy: Evidence from the Cotton Textile Industry, 1861-1914." Economic History Review 51, no. 4 (1998): 734-62.

Baldwin, Robert. Non-Tariff Distorsions of International Trade, Washington: Brookings, 1970.

Besso, Sabbato. The Cotton Industry in Switzerland, Vorarlberg and Italy. A Report. Manchester: Manchester University Press, 1910.

Caizzi, Bruno. Storia dell'industria italiana: dal XVIII secolo ai giorni nostri. Torino: Utet, 1965.

Calzavarini Mirella. "Il protezionismo industriale e la tariffa doganale del 1887." Clio 2 (1966): 55-93.

Cardwell, Donald. The Fontana History of Technology. London: Harper, 1994.

Comín, Francisco Comín, Pablo Martin Acena, Miguel Munoz Rubio, 150 Anos de Historia de los Ferrocarriles Espanoles, Madrid, Fundacion de los Ferrocarriles Españoles, 1998.

Cayón García, Francisco, and Miguel Muñoz Rubio. "Que fabriquen ellos! La fabricacion de locomotoras de vapor en España: una ocasion perdida para la industria” Working Paper, Universidad Autónoma de Madrid, Madrid, 2005.

Cianci, Ernesto. Dinamica dei prezzi delle merci in Italia dal 1870 al 1929. Rome: Istituto Poligrafico, 1933.

Ciccarelli, Carlo, and Fenoaltea, Stefano. "The Rail-Guided Vehicles Industry in Italy, 1861-1913: The Burden of the Evidence." Research in Economic History 28 (2012): 43-116.

Ciccarelli, Carlo and Fenoaltea, Stefano. La produzione industriale delle regioni d'Italia, 1861-1913: una ricostruzione quantitativa. 2. Le industrie estrattivo-manifatturiere. Rome: Bank of Italy, 2014.

Ciccarelli, Carlo, and Nuvolari, Alessandro. "Technical Change, Non-Tariff Barriers and the Development of the Italian Locomotive Industry, 1850-1913." Economic History Working Papers, Bank of Italy, 2015, available at https://www.bancaditalia. it/pubblicazioni/quaderni-storia.

Colombo, Giuseppe. "Sui progressi compiuti nell'industria delle macchine dall' epoca dell' Esposizione di Firenze ad oggi." In L'Italia Industriale nel 1881. Conferenze sulla Esposizione Nazionale di Milano, edited by Francesco Brioschi. Milan: Hoepli, 1881.

Cornolò, Giovanni. Locomotive a vapore. (2nd ed.) Parma: Albertelli Editore, 1998.

Diegoli, Manlio. "La trazione a vapore." In Evoluzione tecnica ed economica delle ferrovie nei cento anni dall'Unità d'Italia, 1861-1961, edited by Collegio ingegneri ferroviari italiani, 105-14. Rome: Tipografia Pio X, 1961.

Ericson, Steven. "Importing Locomotives in Meiji Japan: International Business and Technology Transfer in the Railroad industry." Osiris 13, no. 1 (1998): 129-53. 
Fagerberg, Jan. "Technology and International Differences in Growth Rates.” Journal of Economic Literature 32, no. 3 (1994): 1147-175.

Federico, Giovanni, and Giannetti, Renato. "Le politiche industriali." In Storia d' Italia. Annali. L'Industria, edited by F. Amatori, D. Bigazzi, R. Giannetti, and L. Segreto. Turin: Einaudi, 1999.

Federico, Giovanni, and Tena, Antonio. "Did Trade Policy Foster Italian Industrialization

? Evidence from Effective Protection Rates." Research in Economic History 19 (1999): 111-30.

Fenoaltea, Stefano. "Italy." In Railways and the Economic Development of Western Europe, edited by Patrick O'Brien, pp. 49-120. London: Macmillan, 1983.

- The Reinterpretation of Italian Economic History. Cambridge, MA: Cambridge University Press, 2011.

Giordano, Felice. L'industria del ferro in Italia; relazione dell'ingegnere Felice Giordano per la Commissione delle ferriere istituita dal Ministero di marina. Turin: Cotta \& Capellino, 1864.

Gerschenkron, Alexander. Economic Backwardness in Historical Perspective. Cambridge MA: Harvard University Press, 1962.

Giannetti, Renato, and Vasta, Michelangelo. Storia dell' impresa italiana. Bologna: il Mulino, 2012.

Greggio, Luciano, and Kalla-Bishop, Peter. Steam Locomotives. New York: Crescent Books, 1985.

Hertner, Peter. Il Capitale Tedesco in Italia dall'Unità alla Prima Guerra Mondiale. Bologna: Il Mulino.

Landes, David S. The Unbound Prometheus. Technological Change and Industrial Development in Western Europe from 1750 to the Present. Cambridge, MA: Cambridge University Press, 1969.

Licini, Stefania. "Dall'Elvetica alla Breda. Alle origini di una grande impresa milanese (1846-1918)." Società e Storia 63 (1994): 79-123.

Loria, Leonardo. "Il materiale ferroviario" In L' Italia Industriale nel 1881. Conferenze sulla Esposizione Nazionale di Milano, edited by Francesco Brioschi. Milan: Hoepli, 1881.

Merger, Michèle. "Un modello di sostituzione: la locomotiva italiana dal 1850 al 1914." Rivista di storia economica 3, no. 1 (1986): 66-108.

—. 'L'Industrie italienne de locomotives, reflet d'une industrialisation tardive et difficile (1850-1914)." Histoire, économie et société 8, no. 3 (1989): 335-70.

Papa, Antonio. Classe politica e intervento pubblico nell'età giolittiana. La nazionalizzazione delle ferrovie. Naples: Guida, 1973.

Pareto, Vilfredo. "Le industrie meccaniche e la protezione." Giornale degli Economisti 2 (1891): 308-12.

Popescu, Ilie. Căi ferate - transporturi clasice şi moderne. Bucarest: Editura Stiintifica si Enciclopedica, 1987.

Romeo, Rosario. Risorgimento e capitalismo. Bari: Laterza, 1959.

Scranton, Philip. Endless Novelty. Specialty Production and American Industrialization, 1865-1925. Princeton: Princeton University Press, 1997.

Schram, Albert. Railways and the Formation of the Italian State in the Nineteenth Century. Cambridge: Cambridge University Press, 1997.

Sereni, Emilio. Capitalismo e mercato nazionale in Italia. Rome: Editori Riuniti, 1966. 
Sinclair, Angus. The Development of the Locomotive Engine. New York: Sinclair, 1907. Tey, Giovanni. La locomotiva a vapore. Storia, sviluppo e perfezionamento al 1910. Milan: Vallardi, 1910.

Toniolo, Gianni. "Effective Protection and Industrial Growth: The Case of Italian Engineering.” Journal of European Economic History 6, no. 3 (1977): 659-73.

Van Dijk, Michiel, and Adam Szirmai. "Industrial Policy and Technology Diffusion: Evidence from Paper Making Machinery in Indonesia." World Development 34, no. 12 (2006): 2137-52.

Vasta, Michelangelo. "Le innovazioni tecnologiche" In Storia dell'Ansaldo. Vol 9, edited by Valerio Castronovo, pp. 225-59.Rome-Bari: Laterza, 2002.

\section{OFFICIAL PUBLICATIONS}

Camera dei Deputati, Atti parlamentari. Legislatura XI, Sessione 1871-72, Documenti, Doc. 39-A, Rome, 1871.

-. Atti parlamentari. Legislatura XVI, $2^{a}$ Sessione 1887-88, Documenti, Doc. 169, Sub-Allegato 2, Rome, 1888.

—. Atti parlamentari. Legislatura XXII, Sessione 1904-06, Documenti, Doc. 29, Rome, 1906a.

—. Atti parlamentari. Legislatura XXII, $1^{a}$ Sessione, Discussioni, Tornata del 15 marzo 1905, Rome, 1906b.

- Atti parlamentari. Legislatura XXII, Sessione 1904-06, Documenti, Doc. 359, Rome, 1906c.

Comitato dell'inchiesta industriale. Atti. Deposizioni scritte, categoria 15 \$3. Macchine, Rome, 1872.

- Atti. Deposizioni scritte, categoria $15 \S 2$. Industrie metallurgiche, Rome, 1873.

- Atti. Riassunti delle deposizioni orali e scritte, categoria 15 § 3. Macchine, Florence, 1874.

Commissione d'inchiesta per la revisione della tariffa doganale. Atti. II. Parte industriale. Relazione del deputato Vittorio Ellena, Rome, 1886.

Commissione d'inchiesta sull'esercizio delle ferrovie italiane. Atti. Parte I. Verbali delle sedute pubbliche. Volume I, Rome, 1879.

Ferrovie dello Stato. Direzione generale. Servizio trazione. Locomotive ed Automotrici in servizio e in costruzione al 30 giugno 1914, Florence, 1914.

Ministero dei lavori pubblici. Regio ispettorato generale delle strade ferrate. Relazione sulle costruzioni e sull'esercizio delle strade ferrate italiane per gli anni 18851886-1887, vol. II, Rome, 1889.

- Relazione intorno all'esercizio delle strade ferrate delle reti mediterranea, adriatica e sicula dal $1^{\circ}$ luglio 1885 al 1900, parte IV, vol. II, Rome, 1901.

Ministero delle finanze. Direzione generale delle gabelle. Movimento commerciale del Regno d'Italia nell'anno 1874, Florence, 1874.

- Movimento commerciale del Regno d'Italia nell'anno 1888, Rome, 1889.

Società Italiana Ernesto Breda, Per la millesima locomotiva, Milan, 1908.

—. La Società italiana Ernesto Breda per costruzioni meccaniche: dalle sue origini ad oggi, 1886-1936, Verona, 1936. 
Società Italiana per le Strade Ferrate Meridionali. Esercizio della rete adriatica, Tipi delle locomotive e dei tenders. Anno 1887, s.1., 1887 ca.

Società Italiana per le Strade Ferrate del Mediterraneo, Album delle locomotive 1888, Turin, 1888.

Società Italiana per le Strade Ferrate della Sicilia, Materiale rotabile. Tipi delle locomotive e delle carrozze, Palermo, 1902 ca. 